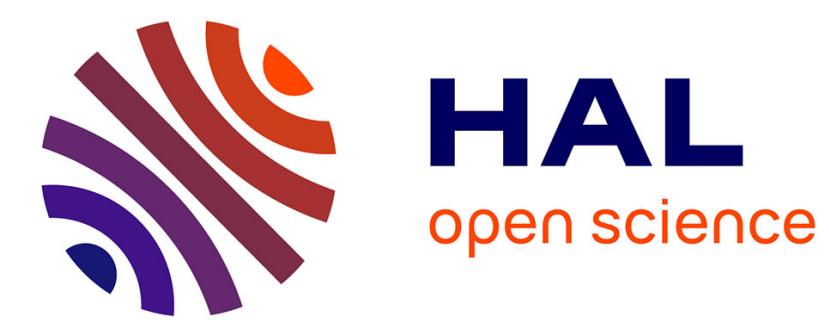

\title{
The effects of innovation on employment in developing countries: evidence from enterprise surveys
}

\author{
Xavier Cirera, Leonard Sabetti
}

\section{To cite this version:}

Xavier Cirera, Leonard Sabetti. The effects of innovation on employment in developing countries: evidence from enterprise surveys. Industrial and Corporate Change, 2019, 28 (1), pp.161-176. 10.1093/icc/dty061 . hal-03182320

\section{HAL Id: hal-03182320 \\ https://hal.uca.fr/hal-03182320}

Submitted on 19 Nov 2021

HAL is a multi-disciplinary open access archive for the deposit and dissemination of scientific research documents, whether they are published or not. The documents may come from teaching and research institutions in France or abroad, or from public or private research centers.
L'archive ouverte pluridisciplinaire HAL, est destinée au dépôt et à la diffusion de documents scientifiques de niveau recherche, publiés ou non, émanant des établissements d'enseignement et de recherche français ou étrangers, des laboratoires publics ou privés. 


\title{
The Effects of Innovation on Employment in Developing Countries. Evidence from Enterprise Surveys
}

\author{
Xavier Cirera \\ The World Bank Group, Washington, D.C. \\ Corresponding author: xcirera@worldbank.org \\ Leonard Sabetti \\ Université d'Auvergne, Clermont Ferrand (France) \\ leonard.sabetti@etu.udamail.fr
}




\title{
The Effects of Innovation on Employment in Developing Countries: Evidence from Enterprise Surveys ${ }^{1}$
}

\begin{abstract}
This paper sheds light on the direct impact of technological as well as organizational innovation on firm level employment growth using a global sample of over 15,000 firms in developing countries. The main findings suggest that new sales associated with product innovation are produced, on average, with just as much or higher levels of labor intensity than old products. However, the additionality to employment decreases with productivity, proxied by income per capita. In line with other studies, process innovation does not impact the additionality of employment, but there is some evidence of automation reducing the impact of product innovation on employment.
\end{abstract}

\section{Introduction}

Innovation is the engine of the creative destruction process that spurs economic dynamism and transformation (Schumpeter 1942). At the macro level, theories of economic growth put innovation at the center of the growth process since Solow's (1957) seminal work, where economic growth is driven by technical change. The emergence of new growth theory emphasized the role of innovation and knowledge accumulation in the growth process and Schumpeterian creative destruction arising from a competitive $R \& D$ sector as the main engine of economic growth (Aghion and Howitt (1992); Romer, 1986). 
At the firm level, Klette and Kortum (2004) show how innovation activities create rich firm-level dynamics that translate into firm growth. Unlike previous models where firm growth was largely driven by firm learning, in the model of Klette and Kortum (2004), innovation increases product quality and makes firms more competitive, which increases their revenue and size and forces existing firms producing old and obsolete versions of the product to exit the market.

While innovation has the potential to generate large productivity gains and significantly improve allocative efficiency, ${ }^{2}$ the short-term direct impacts of innovation on employment remain an important policy question, especially in a developing country context where firms operate far from the technological frontier. While the introduction of new product lines tend to generate employment, new processes using more modern technologies or upgraded products can result in more efficient use of labor or labor replacement. Determining what the tradeoff might be (if any) between innovation and employment growth is critical for policy, especially in developing countries where the needs to absorb new entrants to the labor market in formal and higher productivity jobs are greatest.

This paper tries to shed some light to this tradeoff and estimates the short-run direct impact of firm-level innovation on employment in a sample of developing countries, using a novel dataset on firm innovation activities for a large set of developing countries. Our contribution to the literature is threefold. First, we expand the existing evidence on employment effects to a large number of low and middle-income countries, taking advantage of a unique firm survey implemented in 53 countries by the World Bank Enterprise Surveys Unit. Second, we attempt to disentangle the effects of process innovation from product innovation on employment when both are implemented simultaneously, as well as isolating 
the impact of automation from process innovation more broadly. Finally, we study how the degree of novelty of innovation - new to the firm vs new to national or international market and the level of a country's development, as a proxy for aggregate productivity, affect the elasticity of innovation to employment. Given the nature of the data we use, our results focus on average, short-run effects at the firm-level; an important building block to arriving at aggregate or sector level effects on employment, which inform welfare considerations.

This paper is structured as follows. The next section briefly summarizes the existing evidence, mainly for OECD countries, regarding the impact of innovation on employment. Section 3 describes the data, while section 4 develops the methodological framework used in the empirical section. Section 5 describes the main empirical findings. The last section concludes.

\section{The Direct Impact of Innovation and Employment}

Innovation is the outcome of firms' investments in knowledge capital, managerial practices and organizational decisions. The ultimate objective of these investments is to introduce new or upgraded products or processes that positively impact firm performance by increasing productivity, sales, profits or markups. However, there is uncertainty regarding the extent to which firms are able to convert knowledge capital investments into innovation outcomes and furthermore, whether these innovation outcomes are likely to impact firm performance. This uncertainty is particularly high in developing countries, where there is a lack of key complementary factors such as skills, managerial and organizational or technology 
capabilities to support innovation. The impact of innovation on employment depends on the allocation of workers complementing innovations, and the impact of these innovation efforts on firms' efficiency.

To date, most of the evidence on the impact of innovation on employment has focused on developed countries. Some of the case study literature has emphasized the role of innovation as a force for skill-biased technological change; since increases in firm efficiency can result in more efficient use of labor and changes in the relative demand for skilled labor. Few empirical studies, however, have found a direct negative impact on employment; although the bulk of studies suggest strong evidence of skill-biased technological change. From a theoretical standpoint, predicting the effects of innovation on employment can be ambiguous. While product innovation is typically aimed at increasing a firm's demand through the introduction of a new product, process innovation usually entails production enhancements that can be labor saving. The existence of these competing mechanisms makes the net effects uncertain.

A strand of the literature has analyzed the impact of technology adoption on employment focusing on the general equilibrium effects in the labor market and labor polarization. Brynjolfsson and McAfee (2012) suggests that new digital technologies are having a structural impact on employment and are to blame for jobless growth. Frey and Osborne (2016) using data on occupations for the US labor market predict that about $47 \%$ of US jobs could be at risk due to computerization. Autor and Dorn (2013) suggest that the falling cost of automating routines and codifiable job tasks are one of the main determinants of the polarization of employment and wages in the US labor market. A common finding of this employment literature is the fact that new technologies, especially via automating 
routines, are having a strong impact on labor demand and the relative returns to different labor tasks and skill intensities.

In contrast, the empirical literature examining the direct impact of innovation on firmlevel employment, while providing support to the existence of skill-biased technical change, has been more positive about the impact on labor (see Vivarelli (2012) and Calvino and Virgillito (2018) for overviews and other articles in this volume). ${ }^{3}$ Overall, this literature finds a positive direct link between product innovation and firm level employment. Harrison et al. (2014) find positive innovation to employment elasticities close to unity for France, Germany, Spain and the UK; while Crespi and Tacsir (2013) find also very similar results for Chile, Argentina, Costa Rica and Uruguay. A more puzzling result, however, in some of these studies is the fact that the effects of process innovation are ambiguous.

\section{Methodology}

\subsection{Baseline specifications}

To examine the impact of innovation on firm-level employment we adopt the empirical approach based on the model developed in Harrison, Jaumandreu, Mairesse, and Peters (2014). This model is well suited for cross-sectional data that contain information on a firm's current activities as well as its growth in sales and employment over a recent period. The crucial component of the model is the share of current sales due to newly introduced or improved products which is reported in our data, and that captures the extent of innovation. In this section, we briefly review key aspects of the methodology and our extensions to the 
model; we refer the reader to the Harrison et al. (2014) paper, and Crespi et al. (2018) in this volume for a detailed exposition.

Under this framework, the impact of innovation on employment depends on product innovation, process innovation and the relative efficiency parameters. The effect of product innovation on employment growth is represented by the difference in efficiency between the production processes of old and new products. When new products are produced more efficiently than old ones, output growth due to new products leads to smaller increases in employment compared to old products. The relative efficiency parameter could also be capturing to what extent product innovations are geared towards being more cost effective versus improving quality, which are arguably labor eroding and enhancing, respectively. While the relative efficiency parameter is firm specific, the country average could be correlated with the level of development of the country or the type of innovation introduced, given that firms in more advanced countries may be more capable to improve relative efficiency of new products.

While product innovations are not necessarily related to changes in the efficiency of production, process innovations are typically directed towards improvements in efficiency. A further complication arises when a firm introduces both product and process innovations simultaneously. A priori, it is difficult to predict the relative efficiency of ex post firm-level innovation, and will depend on the combination of innovation outcomes and the degree of efficiency of the firm.

Following Harrison et al. (2014), our reduced form estimating equation is as follows:

$$
l_{i}-g_{1 i}=\alpha_{0}+\alpha_{1} d_{i}+\beta g_{2 i}+u_{i}
$$


where $l$ stands for rate of employment growth over the period (i.e., between the year $t=0$ and $t=2), g_{1}$ and $g_{2}$ are corresponding rates of nominal sales growth for old and new products, and $u$ is the unobserved random disturbance. The change in average efficiency in the production of old products is denoted as $\alpha_{0}$ and $d_{i}$ includes an additive component for process-only innovators; $\beta$ measures the relative efficiency gains from the production of new products.

As discussed in Harrison et al. (2014), sales growth due to new products, ga, can be correlated with the error term leading to a downward bias in $\beta$. This correlation can be driven by: 1) economic factors such as unobserved productivity shocks affecting both the decision to innovate and sales growth, and 2) measurement error when using nominal sales due to the lack of observed prices and appropriate price deflators. Instrumental variable (IV) methods are used to deal with the endogeneity stemming from the measurement issue while it is assumed that endogeneity effects from unobserved productivity shocks are more benign given timing differences. Variables that explain the success of the product innovation's sales but that are uncorrelated with its price differences relative to the old product should serve as good instruments. We use a series of indicator variables that measure whether the product innovation was geared towards extending the market, whether the firm invests in $R \& D$, and whether the innovation is completely new to the firm; these variables do not imply any necessary impact on prices. In all estimates, we evaluate and report the strength of our instruments as suggested in Stock and Yogo (2005) and conduct Sargan-Hansen overidentification tests. 


\subsection{Extensions to the baseline model}

We consider some extensions to augment our baseline findings on the impact of different types of innovation on employment. First, firms can also introduce organizational innovations, which lead to change in the organizational structure of the firm such as departments or units within the firm, and that can also affect efficiency and the level of employment. Thus, we extend the original model in (1) to include the impact of organizational innovation on employment to also affect the relative or trend efficiency term.

$$
l_{i}-y_{1 i}=\alpha_{0}+\alpha_{1} d_{i}+\alpha_{2} \operatorname{org}_{i}+\beta y_{2 i}+u_{i}
$$

Second, the net impact of product and process innovation is not fully identified in (1), since the relative efficiency term in $\beta$ reflects both types of innovation when implemented simultaneously. Section 3.3 reviews an approach to further disentangle the impacts of product and process innovation on employment.

A final extension of the model is related to the definition of process innovation. The way process innovation is defined in most innovation surveys using Oslo-manual guidelines includes any improvements on production or delivery methods, which can range substantially in their impact on efficiency and employment. Following the literature emphasizing the impact of automation on employment, we extend the model and decompose process innovation between innovations that imply some degree of automation in the production process and other types of process innovation. 


\subsection{Accounting for heterogeneity of impact}

In our benchmark analysis, we pool the data and estimate equation (4) with controls for each country and sector. However, there are strong reasons to believe that unobserved heterogeneity can play a role at the country and sector level, given existing technology differences. In order to account for these differentiated effects, we extend the model to estimate random intercepts and coefficients for different clusters, defined by pairs of country and sectors (see Rabe-Hesketh and Skrondal, 2012, for more details on the random effects model).

Rewriting equation (1) as:

$$
l_{i j}-g_{1 i j}=\alpha_{0}+\alpha_{1} d_{i j}+\beta g_{2 i j}+u_{i j}
$$

where $i$ indexes over the firm and $j$ represents a distinct industry within a particular country. For any two firms from the same country and sector, it might be unrealistic to assume that the residuals $u_{i j}$ and $u_{i^{\prime} j}$ are uncorrelated. We decompose the total residual or error, $u_{i j}$, into a shared component between firms in the same country and sector group or cluster, $\xi_{1 j}$, and a firm specific component, $\varepsilon_{i j}$, that represents the within group residual - referred to as level-2 and level-1 residuals, respectively. Similarly, we can specify a country and sector specific random slope, $\xi_{2 j}$, that affects $g_{2}$ in addition to the fixed component, $\beta$. As a result, we allow the intercept and slope to vary by each country's sector. The model becomes,

$$
l_{i j}-g_{1 i j}=\left(\alpha_{0}+\xi_{1 j}\right)+\alpha_{1} d_{i j}+\left(\beta+\xi_{2 j}\right) g_{2 i j}+\varepsilon_{i j}
$$


where it is assumed that the random effects have zero means conditional on observables and the level-1 error term has zero mean given the covariates and random effects:

$$
E\left(\varepsilon_{i j} \mid \mathbf{X}_{\mathbf{j}}, \xi_{1 \mathbf{j}}, \xi_{2 \mathbf{j}}\right)=\mathbf{0}
$$

Furthermore, given $\mathbf{X}_{\mathbf{j}}$ the random intercept and random slope follow a bivariate distribution assumed to have zero mean and covariance matrix $\Psi .{ }^{4}$ The model is estimated via maximum likelihood with bootstrapped standard errors after obtaining predicted values of growth in new sales, $\mathrm{g}_{2}$, in a first-stage equation as in the IV approach outlined in the previous section. ${ }^{5}$

The country and industry specific components, $\xi_{i j}$, represent the combined effects of omitted variables or unobserved heterogeneity at the country and industry level. Because of the shared components, the model accounts for within-country and sector dependence among the total residuals. The random intercepts and slopes can be interpreted as latent variables whose variance terms are estimated along with the other parameters and the variance term of the level 1 residual $\varepsilon_{i j}$. However, after estimating the model's parameters, including the random intercept and random slope variances as well as their covariance, $\widehat{\psi_{11}}, \widehat{\psi_{22}}, \widehat{\psi_{21}}$, we can obtain estimates of the random intercepts and slopes by an auxiliary regression that regresses the predicted total residuals on $g_{2 i j}$ and a constant term. ${ }^{6}$

The added advantage of exploiting within country and sector variation is that it allows us to try to disentangle the impact of different types of innovation measured by $\beta$ in equation (4) discussed above. While the estimate of $\beta$ is unbiased econometrically, to disentangle the true impact of product from process innovation on employment we would need to decompose this coefficient. We do so by exploiting the variance across the estimated country-sectors 
coefficients from the random-coefficient model, $\beta+\xi_{2 j}$, which are regressed on the intensity of product, process and organizational innovation in each country-sector cluster. Thus, the following equation is estimated:

$$
\beta_{j}=\alpha+\gamma \mathbf{w}_{\mathbf{j}}+u_{1 j}
$$

where $j$ denotes the country and sector, $\alpha$ is a constant term and $\mathbf{w}_{\mathbf{j}}$ is a vector of innovation intensity measures representing the incidence of innovation outcomes in each country-sector group. Although imperfect, given the aggregation of the data to the country-sector level, this

two-stage estimation allows us to explore the effect of combining different types of innovation with product innovation on the impact of sales from new products on employment.

\section{The Data}

In order to examine the innovative behavior of firms in developing countries, we use the World Bank 2013-2015 Enterprise Survey and its linked innovation modules. This is the most comprehensive set of cross-country surveys on innovation with the same sampling methodology and questionnaire carried out to date. The survey uses a stratified sampling strategy, where firms are stratified by industry, size, and location; and large and medium size firms tend to be over represented. An advantage of the survey is that it collects substantial balance sheet and other information regarding the investment climate, which enables the linkage of innovation efforts to performance and potential obstacles. ${ }^{7}$ The mode of data collection is face-to-face interviews. 
The innovation survey differentiates between product and process innovation, and two non-technological innovations, marketing and organization. However, there is significant confusion when identifying the different types of innovation outcomes by firms in the survey. For example, new marketing processes such as discounts, new packaging or new client segments are sometimes identified with process or product innovations. The fact that interviewees provide a recorded description of the product and process innovations allows us to verify the identified product and process innovations, and clean the wrongly attributed cases, or the cases that do not constitute an innovation at all (the detailed methodology to clean the data is described in the Cirera and Sabetti, 2016). Overall the cleaning exercise results in a significant decrease in both product and process innovation rates. ${ }^{8}$

Our final data set consists of samples of firms from 53 countries in manufacturing and services across four major regions: Africa, Europe-Central Asia (ECA), Middle-East and North Africa (MENA), and South Asia. In total our estimation sample is based on pooled cross-sections totaling over 15,000 firms where sufficient information on innovation and employment is available. ${ }^{9}$ Firms report both their sales and employment in the year the survey was conducted, which for most firms surveyed was in 2013 or 2014, as well as three years prior. In addition, firms report information about their innovation activities, such as product and process innovations but also including organization innovations, and the share of sales attributed to new innovations that allows us to decompose employment growth into its respective components driven by old products and new products growth.

Table 1 reports the number of firms in our sample across regions and by type of firm measured in terms of size, age and sector. Overall, we observe that the firms in our sample 
tend to be small, with fewer than 20 employees, and at the same time tend to be older, with the majority of firms operating for more than 10 years.

Table 1 in here

\section{Results}

\subsection{Employment and sales growth among innovators and non- innovators}

Table 2 compares firm employment and sales growth rates over the three-year period from the year in which the survey was completed, according to whether firms are non-innovators, process-innovators only, product innovators, and if so, whether they are also engaged in process innovation, by manufacturing and services sectors respectively. Innovation is larger in manufacturing than in services; and process and organizational innovation are the less prevalent types of innovation; although process innovation is more prevalent when combined with product innovation than organizational innovation. In manufacturing, roughly $46 \%$ of firms report undertaking some form of innovation, with roughly $27 \%$ of firms reporting product innovations. Slightly over half of firms with product innovations have also introduced process innovations.

Table 2 in here

The rate of technological innovation is strikingly large in Africa and South Asia. Rates for innovations defined as new to the national or international market are much lower, and the gap between new to the firm and new to the national market is significantly large for Africa 
and other low-income countries. Radical innovations - innovations new to the international market - and patenting are rare in these countries. Overall, this suggests large imitation rates in these regions, and the fact that many of the innovations that are new to the firm in most of the countries in our sample are likely to be marginally incremental; such as new product additions or small improvements.

On average, firms that have introduced product and/or process innovations tend to display higher growth rates both in employment and sales, although these differences are not statistically significant. Interestingly, when decomposing sales growth for product innovators into respective shares made up of old and new products, we observe that sales growth for old products tends to be negative. As a result, much of the overall sales growth for these firms tends to be driven by new products, which might be due to cannibalizing old products. We also find that the cumulative distribution functions of employment and sales growth for innovators, segmented by firm size, do not stochastically dominate those for non-innovators. However, we observe some evidence that innovating firms exhibit higher growth rates for parts of the distribution, particularly for larger firms.

Table 2 also highlights the challenge described in section 3 when trying to disentangle the employment effect of product and process innovation. Around half of product innovators in manufacturing and $30 \%$ in services also implement process innovation. In these cases, process innovations are also likely to affect the productivity terms of the new products introduced. 


\subsection{The impact of innovation on employment}

\subsubsection{The impact of innovation on employment growth}

Table 3 shows the results of estimating equation (1) by OLS for the pooled sample and by different geographical and income regions, using process innovation only dummy, sectorcountry and size dummies. ${ }^{10}$ Starting with the coefficient of process innovation only, this is negative and statistically significant, with the exception of ECA, MENA and high-income countries; suggesting that cases where firms only introduce new processes, increases in efficiency can result in a decrease in employment growth. Adding the process innovation only coefficient to the constant term allows retrieving the original intercept that reflects the trend productivity term of old products with negative sign. ${ }^{11}$ The trend productivity parameter $(-\alpha)$ is negative for Africa, MENA and low-income countries sample, which suggests that labor productivity for all products in these regions have decreased. For the entire sample, the trend productivity parameter is positive for process innovators only, and also positive for all firms in South Asia, ECA and high-income countries.

Table 3 in here

The main coefficient of interest, the elasticity of sales attributed to product innovation on employment growth, is statistically significant and positive in all specifications, and 0.6 on average for the whole sample. Interestingly, the coefficient is below unity in all OLS specifications, which implies that new products are produced more efficiently than old products as in equation (2) and suggests a positive but less than proportional employment elasticity to innovative sales that results in some labor displacement. This elasticity is also 
larger in the MENA and South Asia region and middle-income countries in general; suggesting lower efficiency impacts arising from innovation.

However, as discussed in section 3, OLS estimates are likely to be biased due to the endogeneity of the sales growth of new products when the true real change in growth of sales is unobserved due to the lack of appropriate price deflators. To correct for this potential endogeneity, Table 4 shows the instrumental variables estimations. As instruments for sales growth from new products, we follow Harrison et al. (2014) and use variables that are correlated with the success of the innovation but that do not necessarily imply any directional change in prices of new products relative to old ones; a dummy for whether the product is completely new to the firm and whether the firm invests in R\&D. R\&D investments and innovation decisions are made in advance, prior to any information on prices, and, therefore, unlikely to be correlated with the error term, while important to determine the success in sales terms of the innovation introduced. The Sargan-Hansen Over identification test (Stock and Yogo, 2005) p-value confirms the validity of the instruments used.

The new IV estimates suggest that the previous OLS estimates on the innovation elasticities were biased downwards. The new estimates are also statistically significant but much larger, especially in Africa and to a lesser extent in low and middle-income countries. This suggests that the employment growth associated to product innovations is larger in these lower income regions because of having lower efficiency gains from innovation in new and upgraded products. While these new or upgraded products are able to capture market share, the fact is that most innovation in these regions are marginal - new to the firm and simple upgrades - with little or no efficiency gains. The coefficient is significantly lower in the ECA region and high-income countries, suggesting that innovation in countries closer to the 
technological frontier increases employment less than proportionally driven by the larger impact of innovation on efficiency in this region.

\section{Table 4 in here}

While the size of the elasticities is conditional to the instruments used, the estimates for middle income-countries are similar to those in Crespi and Tacsir (2013) ranging from 1.16 for Argentina to 0.95 in Uruguay, and close to unitary elasticities. The estimates in Table 4 are, however, much smaller to our smaller sample of high-income countries than to Harrison et al. (2014) sample of EU countries that show unitary elasticities for manufacturing and in some countries for services as well.

In contrast, the impact of process innovation only in the instrumented specifications on employment growth is never statistically significant. In addition, regarding the trend productivity parameter of all products, in the instrumented specifications the parameters are not statistically significant, except for the ECA region where it is positive and marginally significantly negative for South Asia, MENA and low-income countries.

Given the fact that these results could be explained by the different sector composition in these regions, we examine how these elasticities vary across aggregate sectors, technological intensity levels and skill intensity. Table 5 examines the employment effects of product innovation according to whether the firm operates in the manufacturing or services sector. We find that $\beta$ is on average higher in manufacturing than in services, but in both cases, we cannot reject that the elasticity is equal to one, suggesting that product innovations are not labor displacing in both sectors. When we disaggregate manufacturing into its degree of technological intensity, measured according to a sector's intensity of R\&D expenditures, we find that the effect increases when comparing low-tech firms to medium- 
high tech firms, from 0.917 to 1.002 ; although again we cannot reject that the elasticities are equal to unity. Columns 5 and 6 of Table 5 display results from splitting the sample of manufacturing firms into those with high intensity of skilled employees and low intensity firms defined as having a share above or below the sector average, respectively. As expected, the coefficient is larger in low skill intensity firms than in high skill intensity firms, suggesting larger employment effects for firms with less skilled employees, again, explained but by lower efficiency gains from innovation in low skill sectors.

Table 5 in here

\subsubsection{Employment effects of more novel types of innovations}

Typically, product innovation range significantly from radical innovations that are new to national or international markets, to cases of marginal product upgrading or introductions of new product lines. It is possible, therefore, that the additional impact on employment from introducing product innovations largely depends on their degree of novelty, since the elasticity depends on relative efficiency; and the more different the new product introduced to existing products, the more likely relative efficiencies differ. On the one hand, more radical innovations may have a larger impact on relative efficiency and as a result on labor displacement. On the other hand, less novel innovations can have a marginal impact on quality attributes and product differentiation, and less so on relative efficiency.

Table 6 displays the results when considering innovation for differing degrees of innovation novelty. First, we consider separately when innovation is a product upgrade versus a completely new product. On the one hand, if the product upgrade is large, $\beta$ in 
equation (1) - the ratio between the efficiency parameter of the old product and the new product - is likely to depart from unity, but with unknown direction. On the other hand, small product upgrades are unlikely to change relative efficiency. In the case of new products, the size and direction of changes is difficult to predict. The estimates show a negative coefficient on product upgrade reducing the elasticity; however, both for manufacturing and services, the coefficient is not statistically significant. Therefore, we do not find different employment elasticities when comparing quality upgrade vs product diversification.

Table 6 in here

We extend the analysis to the degree of "novelty" on innovation and compare innovation defined as new to the firm vs innovations that are new to the national or international market in columns (3) and (4). Again, we should expect changes in relative efficiency correlated with the degree of novelty, and likely in some cases to greater relative efficiency, lowering $\beta$. The results suggest that in manufacturing there is no additional effect in terms of employment of more radical innovations as compared to new to the firm innovation imitation. On the other hand, the results for services suggest a positive employment elasticity premium of more radical innovation. One potential explanation of this is the fact that knowledge transmission in service firms often relies on human and organizational factors more intensively than in manufacturing, where management plays a central coordinating role. This more intensive use of labor, especially skilled labor, can be exacerbated in more radical innovations and, therefore, more than offsetting any labor productivity changes (see Tether, 2003). 


\subsubsection{Process innovation and automation}

Frey and Osborne (2016) discuss how automation and computerization of tasks may eventually render many labor tasks obsolete. One caveat of the previous estimates is the fact that the measure of process innovation mixes very diverse processes, ranging from the introduction of any new process or delivery methods with the introduction of an automated process (see Appendix). Thus, the process innovation dummy is likely to be capturing very different efficiency generating processes.

Table 7 reports estimates of the baseline instrumented model where we decompose process innovation into two components: innovations that involve automation of any process and non-automation innovations. ${ }^{11}$ The estimates suggest that the effects of automation only on employment growth in general are not statistically significant for most sector disaggregation. This suggest that while automation is likely to have significant effects on the skill and task composition of firms, at least in the short-run and when automation only is implemented as an innovation, it does not appear to have a direct impact on firm employment. An exception to this appears to be services where we find a marginal statistical negative effect.

Table 7 in here

\subsubsection{Impact of organizational innovation}

As suggested above, one important type of non-technological innovation that can have an impact on employment growth is organizational innovation. Changes in firms' departments and organizational structure, outsourcing of tasks or management structure changes (see 
Appendix for the definition) are likely to have an impact on employment growth. Table 8 shows the baseline estimates of including an organizational innovation only dummy. Organizational change was only reported in the survey for large and medium size firms, so there is a significant loss of observations when analyzing this type of innovation.

Table 8 in here

The estimates show that as it was the case for process innovation only, organizational innovation only does not seem to impact employment growth in the instrumented regression. Improvements in the organizational structure or outsourcing of tasks do not appear to affect the level of short term employment of the firm when implemented in isolation from other types of innovation.

\subsubsection{Disentangling the effects from different types of innovations}

As discussed above, a large share of firms conducts both product and process innovation simultaneously. As a result, the elasticity on growth in sales due to new products is to some extent also capturing the impact of process innovation when implemented along with a product innovation. Given the nature of our data and the lack of within firm variation, it is difficult to isolate the true effects of each individual type of innovation. As suggested above and given the large heterogeneity of impact across sectors and countries, we estimate the model allowing the elasticities to vary by country and sector pairs $j$, and then in a second stage, estimate how these $\beta_{j}$ are affected by the intensity of innovation in each country-sector; measured by the share of firms in the country-sector doing product and process innovation; organizational innovation and automation.

Table 9 in here 
Table 9 shows the results of estimating the baseline model to obtain the random coefficients, including the estimated standard deviations of the random intercept and random slope and the residual standard deviation needed for estimating the these $\beta_{j}$. Column (1) reports the model with random intercept and slope, where we test whether the random slope is needed in addition to the random intercept. The likelihood ratio test where the null hypothesis $\xi_{j}=0$ is strongly rejected in favor of the random intercept model. The average elasticity estimate of growth in sales of newly introduced or improved products is similar to the results of the fixed effects model in Table 4, where we obtained an estimate of 0.938 . Based on the estimated variance, roughly $95 \%$ of random slopes fall in the interval $(0.962 \pm$ $1.96 \times \sqrt{0.243}$ ). Column (2) implements the same model but includes the effect of organizational innovation only. Column (3) decomposes process innovation into automation and process innovation excluding automation.

Once these $\beta_{j}$ for all country sectors are estimated, Table 10 shows the estimates of the second stage, where we use the variation of these $\beta_{j}$ across country-sectors and analyze their correlation with the share of product innovators in the country-sector, the share of product and process innovators, product and organizational innovators, and product and automation innovators. In each model, we include a specification that controls for sector specific effects that may explain differences in the elasticity of employment growth with respect to the growth in new products, for example the degree of sector capital and labor intensity. The estimates for the share of product innovation across specifications is not statistically significant, suggesting that having more innovators in the country-sector does not affect the size elasticity. The coefficient on product and process innovation is as expected negative in column (1), suggesting that country-sectors that more intensively combine 
product and process innovation have lower elasticities and potential efficiency gains from process innovation that reduces the additionality on employment creation. However, when we control for sector effects in column (2) the coefficient becomes statistically not significant. Overall, our estimates find no impact of the intensity of process innovators on the elasticity of sales of new products on employment, not even when combined with product innovation.

A more interesting picture emerges when using the intensity of product innovation jointly with automation. In this case, we find that the employment elasticity of new sales due to innovation is lower in sectors where product innovations are more likely to be accompanied by automation of production processes. Therefore, while automation alone may not affect short-term employment, when accompanied with product innovation is likely to increase efficiency and reduce the ability of generating additional employment.

\section{Conclusion}

This paper has analyzed empirically the impact of firm-level innovation on employment. The main result of this paper is that product innovation, when successful in bringing additional sales to the firm, has a positive direct impact on employment in the short-run. The extent to which sales cause additional employment, however, is directly related to the impact on efficiency resulting from the innovation process, which seems to vary with the income level of the country. The empirical estimates suggest that in lower and middle-income countries, and especially in Africa, where innovations are more incremental and there may be less efficiency gains due to the innovation, the employment growth associated with a dollar 
increase in sales from innovative products is larger than in middle and high-income countries. In fact, the model estimates predict that for most countries if all products could be replaced by new or upgraded products, the overall level of employment of the firm would be at least as high as the previous level. This is an important finding given some pessimistic views that innovation efforts are often entirely labor saving for the firm. On the other hand, for high income countries, new sales attributable to innovation generate new employment but at lower rates since the new or upgraded products are more efficient in the use of labor than old products, and, therefore, generating some labor displacement.

The findings point towards product innovation as the main channel of employment creation. Organizational innovation does not appear to have any impacts on employment changes, when considered alone or when implemented with product innovation. The same occurs with process innovation, which does not seem to impact employment, even when considering the introduction of automation processes. It is likely that the main effects of these types of innovation are on the type of labor - skill biased technical change - rather than the quantity of labor. However, we find some support to the idea that automation may actually displace labor by reducing the employment elasticity of product innovation when these are introduced jointly.

The implication of these results for policy are important. Innovation policy, when effective in generating additionality on successful innovation activities, even via imitation, can also be an important policy to increase employment in the short-run. This is especially the case for those countries farthest away from the technological frontier, where the effect on employment from generating new sales due to innovation is largest. On the other hand, for 
higher income countries, the additionality impact on employment is lower given their greater ability to generate productivity gains in new products.

More work is, however, needed to better understand the short-run impact of innovation on the skill composition of the firm and the effect of the different types of innovation combined. While innovation is likely to be skill biased, we know very little about the extent of potential skill displacement within the firm, on the job learning and more generally, what the impact on unskilled workers inside innovative firms is. 


\section{References}

Aghion, P., and P. Howitt (1992): "A Model of Growth through Creative Destruction," Econometrica, 60(2), 323-51.

Arrighetti, A., and M. Vivarelli (1999): "The Role of Innovation in the Post entry Performance of New Small Firms: Evidence from Italy," Southern Economic Journal, 65(4), 927-939.

Autor, D. H., and D. Dorn (2013): "The Growth of Low-Skill Service Jobs and the Polarization of the US Labor Market," American Economic Review, 103(5), 1553-97.

Benavente, J. M., and R. Lauterbach (2008): "Technological innovation and employment: complements or substitutes?" The European Journal of Development Research, 20(2), $318-329$.

Brown, J., J. Earle, and D. Lup (2005): "What Makes Small Firms Grow? Finance, Human Capital, Technical Assistance, and the Business Environment in Romania," Economic Development and Cultural Change, 54(1), 33-70.

Brynjolfsson, E., and A. Mcafee (2012): Race Against the Machine: How the Digital Revolution is Accelerating Innovation, Driving Productivity, and Irreversibly Transforming Employment and the Economy. Digital Frontier Press.

Calvino, F. and M.E. Virgillito (2018): "The innovation-employment nexus: a critical survey of theory and empirics", Journal of Economic Surveys, 32(1), 83-117.

Castillo, V., A. Maffioli, S. Rojo, and R. Stucchi (2014): "The effect of innovation policy on SMEs employment and wages in Argentina," Small Business Economics, 42(2), 387-406.

Cirera, X. and L. Sabetti (2016) "The Effects of Innovation on Employment in Developing Countries: Evidence from Enterprise Surveys" Policy Research Working Paper 7775. World Bank, Washington, DC.

Crespi, G. and E. Tacsir (2013) "Effects of innovation on employment in Latin America," MERIT Working Papers 001, United Nations University - Maastricht Economic and Social Research Institute on Innovation and Technology (MERIT).

Dachs, B., and B. Peters (2014): "Innovation, employment growth, and foreign ownership of firms," Research Policy, 43(1), 214-232. 
Frey, C. B., and M. A. Oborne (2016): "The future of employment: how susceptible are jobs to computerisation," Technological Forecasting and Social Change, Volume 114, January 2017, Pages 254-280.

Hall, B. H., F. Lotti, and J. Mairesse (2008): "Employment, innovation, and productivity: evidence from Italian microdata," Industrial and Corporate Change, 17(4), 813-839.

Haltiwanger, J., R. S. Jarmin, and J. Miranda (2013): "Who Creates Jobs? Small versus Large versus Young," The Review of Economics and Statistics, 95(2), 347-361.

Harrison, R., J. Jaumandreu, J. Mairesse, and B. Peters (2014): "Does innovation stimulate employment? A firm-level analysis using comparable micro-data from four European countries," International Journal of Industrial Organization, 35(C), 29-43.

Klette, T. J., and S. Kortum (2004): “Innovating Firms and Aggregate Innovation,” Journal of Political Economy, 112(5), 986-1018.

Rabe-Hesketh, S., and A. Skrondal (2012): Multilevel and Longitudinal Modeling Using Stata, 3rd Edition. StataCorp LP, 3rd edn.

Romer, P.M. (1986) "Increasing Returns and Long-Run Growth," Journal of Political Economy 94: 102-1037,

Schumpeter, J. (1942) Capitalism, Socialism, and Democracy. New York: Harper \& Bros.

Solow, Robert M (1957). "Technical Change and the Aggregate Production Function". Review of Economics and Statistics (The MIT Press) 39 (3): 312-320.

Stock, J., and M. Yogo (2005): Testing for Weak Instruments in Linear IV Regression pp. 80-108. Cambridge University Press, New York.

Tether, B. (2003): "The sources and aims of innovation in services: Variety between and within sectors," Economics of Innovation and New Technology, 12(6), 481-505.

Vivarelli, M. (2012): "Innovation, Employment and Skills in Advanced and Developing Countries: A Survey of the Literature," IZA Discussion Papers 6291, Institute for the Study of Labor (IZA).

Vivarelli, M., and D. Audretsch (1998): "The Link between the Entry Decision and PostEntry Performance: Evidence from Italy," Industrial and Corporate Change, 7(3), 485500. 
Table 1: Sample description

\begin{tabular}{|c|c|c|c|c|c|c|}
\hline & & All & Africa & South Asia & ECA & MENA \\
\hline Total & & 15033 & 1652 & 3322 & 6658 & 3401 \\
\hline \multirow[t]{3}{*}{ Size } & Small $(<20)$ & 0.54 & 0.73 & 0.36 & 0.61 & 0.49 \\
\hline & Medium (20-99) & 0.36 & 0.23 & 0.47 & 0.33 & 0.38 \\
\hline & Large (100+) & 0.10 & 0.04 & 0.17 & 0.06 & 0.12 \\
\hline \multirow[t]{5}{*}{ Age } & $<5$ & 0.05 & 0.13 & 0.04 & 0.05 & 0.01 \\
\hline & 5 to 9 & 0.22 & 0.30 & 0.19 & 0.24 & 0.16 \\
\hline & 10 to 14 & 0.21 & 0.21 & 0.19 & 0.24 & 0.18 \\
\hline & 15 to 19 & 0.19 & 0.12 & 0.17 & 0.23 & 0.18 \\
\hline & $20+$ & 0.32 & 0.22 & 0.41 & 0.23 & 0.46 \\
\hline \multirow[t]{19}{*}{ Industry } & Food & 0.08 & 0.09 & 0.09 & 0.06 & 0.12 \\
\hline & Textiles & 0.04 & 0.02 & 0.07 & 0.02 & 0.04 \\
\hline & Garments & 0.06 & 0.04 & 0.07 & 0.05 & 0.10 \\
\hline & Wood, Paper & 0.03 & 0.03 & 0.04 & 0.03 & 0.02 \\
\hline & Publishing, Printing & 0.03 & 0.03 & 0.02 & 0.03 & 0.03 \\
\hline & Chemicals & 0.03 & 0.02 & 0.06 & 0.02 & 0.03 \\
\hline & Plastics & 0.03 & 0.01 & 0.07 & 0.03 & 0.02 \\
\hline & Non metallic mineral products & 0.03 & 0.02 & 0.04 & 0.04 & 0.01 \\
\hline & Basic metals, products & 0.07 & 0.07 & 0.10 & 0.05 & 0.07 \\
\hline & Machinery & 0.03 & 0.01 & 0.07 & 0.03 & 0.00 \\
\hline & Electronics & 0.04 & 0.01 & 0.10 & 0.03 & 0.01 \\
\hline & Furniture & 0.03 & 0.07 & 0.03 & 0.03 & 0.03 \\
\hline & Construction & 0.05 & 0.04 & 0.02 & 0.08 & 0.03 \\
\hline & Motor vehicle services & 0.03 & 0.05 & 0.02 & 0.03 & 0.02 \\
\hline & Transportation & 0.05 & 0.03 & 0.03 & 0.05 & 0.06 \\
\hline & Wholesale & 0.09 & 0.09 & 0.02 & 0.12 & 0.08 \\
\hline & Retail & 0.18 & 0.24 & 0.07 & 0.24 & 0.12 \\
\hline & Hotels \& Restaurants & 0.06 & 0.12 & 0.05 & 0.04 & 0.06 \\
\hline & IT, Professional services & 0.02 & 0.01 & 0.02 & 0.02 & 0.01 \\
\hline
\end{tabular}

Note: Based on estimation sample covering 53 countries. Source: Enterprise Surveys 2013-2015. 
Table 2: Growth of employment and sales, innovators and non-innovators

\begin{tabular}{|c|c|c|c|c|c|c|c|c|c|c|}
\hline & \multicolumn{3}{|c|}{ Manufacturing } & ECA & MENA & \multicolumn{5}{|c|}{ Services } \\
\hline Non-innovators (\%) & 0.54 & 0.49 & 0.26 & 0.68 & 0.74 & 0.74 & 0.59 & 0.45 & 0.79 & 0.84 \\
\hline Process-innovators only (\%) & 0.18 & 0.23 & 0.31 & 0.12 & 0.09 & 0.10 & 0.22 & 0.23 & 0.07 & 0.07 \\
\hline \multicolumn{11}{|l|}{ Employment growth } \\
\hline All firms & 0.05 & 0.08 & 0.07 & 0.05 & -0.01 & 0.06 & 0.10 & 0.08 & 0.06 & 0.04 \\
\hline Non-innovators & 0.03 & 0.07 & 0.05 & 0.05 & -0.02 & 0.05 & 0.08 & 0.09 & 0.05 & 0.04 \\
\hline Process innovators only & 0.07 & 0.06 & 0.08 & 0.08 & 0.00 & 0.08 & 0.12 & 0.07 & 0.09 & 0.02 \\
\hline Non-innovators & 0.06 & -0.06 & 0.14 & 0.15 & -0.06 & 0.07 & -0.13 & 0.17 & 0.16 & -0.07 \\
\hline Process-innovators only & 0.11 & -0.05 & 0.15 & 0.18 & -0.06 & 0.05 & -0.12 & 0.15 & 0.17 & -0.10 \\
\hline Product innovators & 0.13 & -0.02 & 0.17 & 0.16 & -0.01 & 0.05 & -0.37 & 0.16 & 0.15 & -0.01 \\
\hline of which: Old products & -0.15 & -0.33 & -0.12 & -0.05 & -0.34 & -0.20 & -0.70 & -0.13 & -0.05 & -0.28 \\
\hline New product & 0.30 & 0.28 & 0.34 & 0.25 & 0.28 & 0.26 & 0.23 & 0.36 & 0.24 & 0.25 \\
\hline
\end{tabular}

employees. Sales growth is measured as change in local nominal currency. For product innovators, we measure overall sales growth, sales growth due to old products, and the share of current period sales attributed to New products. Source: Enterprise Surveys 2013-2015. 
Table 3: Effects of innovation on employment (OLS), by Region and Income Categories

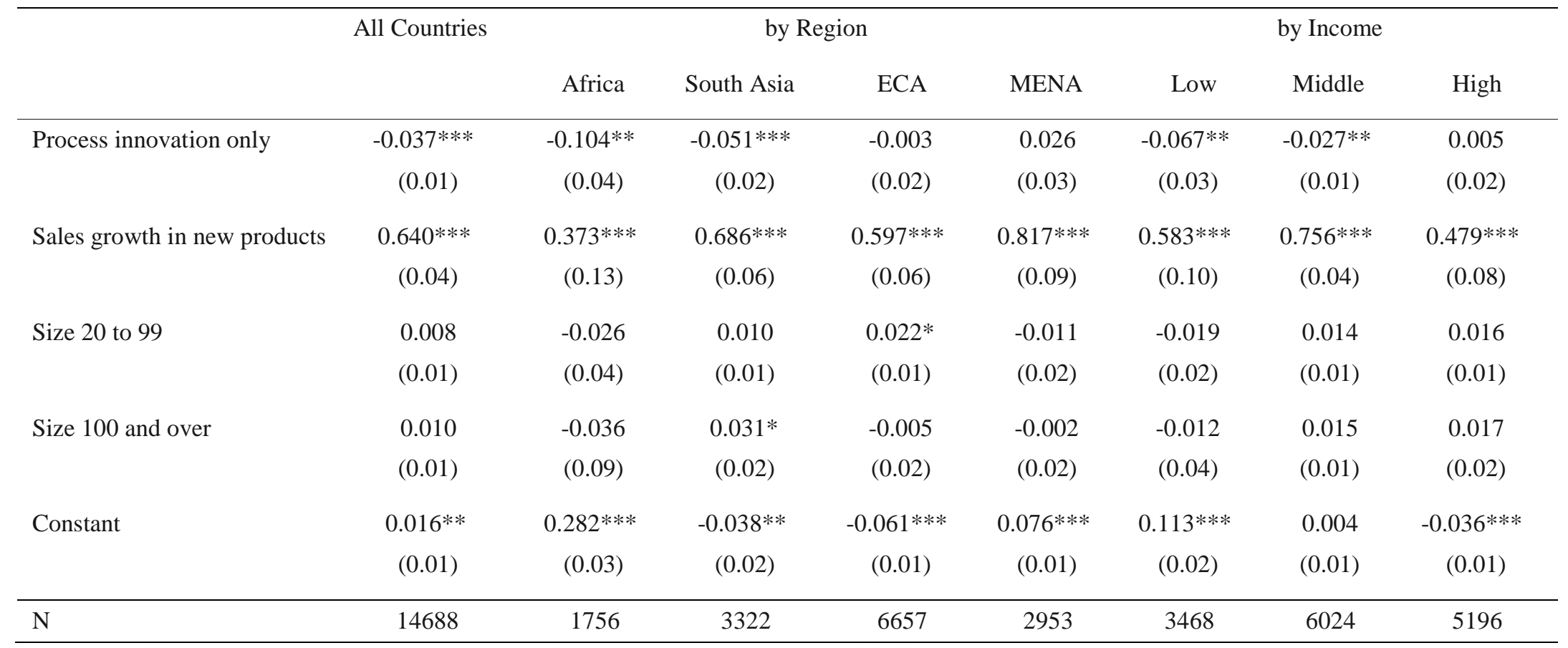

Note: Note: Coefficients and standard errors robust to heteroskedasticity and 1,5, and 10 percent levels of significance are denoted by $* * *, * *$ and $*$, respectively. All

regressions include country-industry and size dummies, constrained to sum to zero. Dependent variable is net labor growth (minus growth in sales of old product). Source:

Enterprise Surveys 2013-2015 
Table 4: Effects of innovation on employment (IV), by Region and Income Categories

\begin{tabular}{|c|c|c|c|c|c|c|c|c|}
\hline & \multirow[t]{2}{*}{ All Countries } & \multicolumn{4}{|c|}{ by Region } & \multicolumn{3}{|c|}{ by Income } \\
\hline & & Africa & South Asia & ECA & MENA & Low & Middle & High \\
\hline Process innovation only & $\begin{array}{l}-0.001 \\
(0.01)\end{array}$ & $\begin{array}{l}-0.000 \\
(0.06)\end{array}$ & $\begin{array}{l}0.004 \\
(0.04)\end{array}$ & $\begin{array}{l}0.007 \\
(0.02)\end{array}$ & $\begin{array}{l}0.034 \\
(0.03)\end{array}$ & $\begin{array}{l}-0.024 \\
(0.03)\end{array}$ & $\begin{array}{l}0.022 \\
(0.02)\end{array}$ & $\begin{array}{l}0.022 \\
(0.02)\end{array}$ \\
\hline Sales growth in new products & $\begin{array}{c}0.938 * * * \\
(0.07)\end{array}$ & $\begin{array}{c}1.726 * * * \\
(0.52)\end{array}$ & $\begin{array}{c}0.945^{* * *} \\
(0.20)\end{array}$ & $\begin{array}{c}0.803 * * * \\
(0.08)\end{array}$ & $\begin{array}{c}1.030 * * * \\
(0.12)\end{array}$ & $\begin{array}{c}1.013^{* * * *} \\
(0.25)\end{array}$ & $\begin{array}{c}1.056^{* * *} \\
(0.10)\end{array}$ & $\begin{array}{c}0.797 * * * \\
(0.10)\end{array}$ \\
\hline Size 20 to 99 & $\begin{array}{l}0.006 \\
(0.01)\end{array}$ & $\begin{array}{r}-0.043 \\
(0.04)\end{array}$ & $\begin{array}{l}0.007 \\
(0.01)\end{array}$ & $\begin{array}{c}0.021 * \\
(0.01)\end{array}$ & $\begin{array}{l}-0.013 \\
(0.02)\end{array}$ & $\begin{array}{l}-0.022 \\
(0.02)\end{array}$ & $\begin{array}{l}0.012 \\
(0.01)\end{array}$ & $\begin{array}{l}0.013 \\
(0.01)\end{array}$ \\
\hline Size 100 and over & $\begin{array}{l}0.005 \\
(0.01)\end{array}$ & $\begin{array}{r}-0.077 \\
(0.09)\end{array}$ & $\begin{array}{l}0.029 \\
(0.02)\end{array}$ & $\begin{array}{l}-0.008 \\
(0.02)\end{array}$ & $\begin{array}{l}-0.008 \\
(0.03)\end{array}$ & $\begin{array}{l}-0.019 \\
(0.04)\end{array}$ & $\begin{array}{l}0.012 \\
(0.02)\end{array}$ & $\begin{array}{l}0.011 \\
(0.03)\end{array}$ \\
\hline Constant & $\begin{array}{l}-0.004 \\
(0.01)\end{array}$ & $\begin{array}{c}0.243^{*} \\
(0.15)\end{array}$ & $\begin{array}{c}0.208^{*} \\
(0.12)\end{array}$ & $\begin{array}{c}-0.133^{* *} \\
(0.06)\end{array}$ & $\begin{array}{c}0.229 * \\
(0.13)\end{array}$ & $\begin{array}{c}0.172 * * \\
(0.09)\end{array}$ & $\begin{array}{l}-0.039 \\
(0.08)\end{array}$ & $\begin{array}{l}-0.086 \\
(0.08)\end{array}$ \\
\hline $\mathrm{N}$ & 14688 & 1756 & 3322 & 6657 & 2953 & 3468 & 6024 & 5196 \\
\hline R-Squared & 0.29 & 0.32 & 0.19 & 0.19 & 0.14 & 0.39 & 0.18 & 0.18 \\
\hline First stage F-statistic & 404.59 & 29.35 & 25.57 & 268.94 & 126.34 & 56.89 & 136.92 & 218.77 \\
\hline Sargan-Hansen test p-value & 0.87 & 0.93 & 0.44 & 0.58 & 0.84 & 0.64 & 0.86 & 0.49 \\
\hline
\end{tabular}


Table 5: Effects of innovation on employment (IV), by Sector and Technological Intensity

\begin{tabular}{|c|c|c|c|c|c|c|c|}
\hline & Manufacturing & Low Tech & Medium Tech & $\begin{array}{c}\text { Medium } \\
\text { High Tech }\end{array}$ & $\begin{array}{c}\text { High Share of } \\
\text { Skilled Workers }\end{array}$ & $\begin{array}{c}\text { Low Share of } \\
\text { Skilled Workers }\end{array}$ & Services \\
\hline \multirow[t]{2}{*}{ Process innovation only } & 0.008 & 0.022 & -0.019 & -0.007 & -0.007 & 0.042 & -0.007 \\
\hline & $(0.02)$ & $(0.02)$ & $(0.05)$ & $(0.06)$ & $(0.02)$ & $(0.04)$ & $(0.02)$ \\
\hline \multirow[t]{2}{*}{ Sales growth in new products } & $0.966 * * *$ & $0.917 * * *$ & $0.894 * * *$ & $1.002 * * *$ & $0.838 * * *$ & $1.189 * * *$ & $0.914 * * *$ \\
\hline & $(0.11)$ & $(0.13)$ & $(0.24)$ & $(0.28)$ & $(0.14)$ & $(0.18)$ & $(0.09)$ \\
\hline Size 20 to 99 & $(0.01)$ & $(0.02)$ & $(0.02)$ & $(0.02)$ & $(0.01)$ & $(0.02)$ & $(0.01)$ \\
\hline \multirow[t]{2}{*}{ Size 100 and over } & 0.012 & 0.022 & -0.020 & 0.008 & 0.010 & 0.015 & -0.013 \\
\hline & $(0.02)$ & $(0.02)$ & $(0.03)$ & $(0.03)$ & $(0.02)$ & $(0.03)$ & $(0.03)$ \\
\hline \multirow[t]{2}{*}{ Constant } & 0.033 & $0.190 * *$ & -0.073 & 0.011 & $0.112 *$ & $-0.180 *$ & -0.006 \\
\hline & $(0.05)$ & $(0.09)$ & $(0.09)$ & $(0.08)$ & $(0.06)$ & $(0.10)$ & $(0.09)$ \\
\hline $\mathrm{N}$ & 7424 & 3875 & 1995 & 1554 & 4784 & 2640 & 7118 \\
\hline R-Squared & 0.23 & 0.25 & 0.27 & 0.23 & 0.28 & 0.27 & 0.34 \\
\hline First stage F-statistic & 144.34 & 104.88 & 25.20 & 18.26 & 80.13 & 48.14 & 286.28 \\
\hline Sargan-Hansen test $\mathrm{p}$-value & 0.90 & 0.40 & 0.66 & 0.14 & 0.74 & 0.31 & 0.60 \\
\hline
\end{tabular}

Note: Coefficients and standard errors robust to heteroskedasticity and 1, 5, and 10 percent levels of significance are denoted by $* * *, * *$ and $*$, respectively. All regressions

include country-industry and size dummies, constrained to sum to zero. Dependent variable is net labor growth (minus growth in sales of old product). Instrumental variables are indicator whether new product is completely new to the firm and whether firms invests in $R \& D$. High and Low Share of skilled workers represent firms with share of

skilled workers above or below the population mean in the most recent fiscal year, respectively. Source: Enterprise Surveys 2013-2015. 
Table 6: Effects of innovation on employment (IV), by Product Innovation Novelty

\begin{tabular}{|c|c|c|c|c|}
\hline & \multicolumn{2}{|c|}{$\begin{array}{l}\text { Product Upgrade vs. } \\
\text { Completely New }\end{array}$} & \multicolumn{2}{|c|}{$\begin{array}{c}\text { New to Firm vs New to National } \\
\text { or International market }\end{array}$} \\
\hline & Manufacturing & Services & Manufacturing & Services \\
\hline Process Innovation only & $\begin{array}{l}0.004 \\
(0.01)\end{array}$ & $\begin{array}{l}-0.007 \\
(0.02)\end{array}$ & $\begin{array}{l}0.013 \\
(0.02)\end{array}$ & $\begin{array}{l}-0.015 \\
(0.02)\end{array}$ \\
\hline Sales growth in new products & $\begin{array}{c}0.963 * * * \\
(0.06)\end{array}$ & $\begin{array}{c}0.918^{* * * *} \\
(0.08)\end{array}$ & $\begin{array}{c}1.031 * * * \\
(0.11)\end{array}$ & $\begin{array}{c}0.742 * * * \\
(0.11)\end{array}$ \\
\hline Product Upgrade $\times$ Sales growth in new products & $\begin{array}{l}-0.043 \\
(0.07)\end{array}$ & $\begin{array}{r}0.100 \\
(0.10)\end{array}$ & & \\
\hline New to National or Intl $\times$ Sales growth in new products & & & $\begin{array}{l}-0.135 \\
(0.10)\end{array}$ & $\begin{array}{c}0.331 * * * \\
(0.12)\end{array}$ \\
\hline Constant & $\begin{array}{l}0.039 \\
(0.05)\end{array}$ & $\begin{array}{l}0.059 \\
(0.09)\end{array}$ & $\begin{array}{l}0.036 \\
(0.05)\end{array}$ & $\begin{array}{l}0.063 \\
(0.09)\end{array}$ \\
\hline $\mathrm{N}$ & 7424 & 7264 & 7424 & 7264 \\
\hline R-Squared & 0.23 & 0.33 & 0.23 & 0.35 \\
\hline
\end{tabular}


Table 7: Process Automation

\begin{tabular}{lcccccc}
\hline & All Firms & Manufacturing & Low Tech & Medium Tech & High Tech & Services \\
\hline Automation only & 0.001 & 0.023 & 0.02 & 0.009 & 0.029 & $-0.106 *$ \\
& $(0.02)$ & $(0.03)$ & $(0.07)$ & $(0.06)$ & $(0.04)$ & $(0.05)$ \\
Process only (excl. automation) & -0.001 & 0.003 & -0.02 & -0.032 & 0.02 & -0.002 \\
& $(0.01)$ & $(0.02)$ & $(0.07)$ & $(0.05)$ & $(0.03)$ & $(0.02)$ \\
Sales growth in new products & $0.941 * * *$ & $0.974 * * *$ & $1.002 * * *$ & $0.898^{* * *}$ & $0.922^{* * *}$ & $0.899 * * *$ \\
& $(0.07)$ & $(0.11)$ & $(0.27)$ & $(0.24)$ & $(0.13)$ & $(0.09)$ \\
Constant & -0.002 & 0.037 & 0.012 & -0.075 & $0.194 * *$ & 0.062 \\
& $(0.01)$ & $(0.05)$ & $(0.08)$ & $(0.09)$ & $(0.09)$ & $(0.09)$ \\
\hline $\mathrm{N}$ & 14688 & 7424 & 1554 & 1995 & 3875 & 7264 \\
\hline
\end{tabular}

Note: Coefficients and standard errors robust to heteroskedasticity and 1, 5, and 10 percent levels of significance are denoted by ***, ** and *, respectively. All regressions include country-industry and size dummies, constrained to sum to zero. Dependent variable is net labor growth (minus growth in sales of old product). Instrumental variables are indicator whether new product is completely new to the firm and whether firms invests in $R \& D$. High and Low Share of skilled workers represent firms with share of skilled workers above or below the population mean in the most recent fiscal year, respectively. Source: Enterprise Surveys 2013-2015. 
Table 8: Effects of innovation on employment, accounting for Organizational Innovation

\begin{tabular}{lcc}
\hline & OLS & IV \\
\hline Process innovation only & $-0.062 * * *$ & 0.021 \\
& $(0.02)$ & $(0.03)$ \\
Organizational only & $-0.068 * * *$ & 0.013 \\
& $(0.02)$ & $(0.03)$ \\
Sales growth in new products & $0.621 * * *$ & $1.118 * * *$ \\
& $(0.05)$ & $(0.12)$ \\
Size 20 to 99 & -0.003 & -0.006 \\
& $(0.01)$ & $(0.02)$ \\
Size over 100 & 0.000 & -0.004 \\
& $(0.000)$ & $(0.02)$ \\
Constant & $0.074 * * *$ & 0.070 \\
& $(0.01)$ & $(0.08)$ \\
\hline N & 4404 & 4404 \\
First stage F-statistic & 0.35 & 0.31 \\
Sargan-Hansen test p-value & & 109.43 \\
\hline
\end{tabular}

Note: Coefficients and standard errors robust to heteroskedasticity and 1,5, and 10 percent levels of significance are denoted by $* * *, * *$ and *, respectively. All regressions include country-industry and size dummies, constrained to sum to zero. Dependent variable is net labor growth (minus growth in sales of old product). Instrumental variables are indicator whether new product is completely new to the firm and whether firms invests in R\&D. Source: Enterprise Surveys 2013-2015. 
Table 9: Effects of innovation on employment, baseline model to compute random coefficients

\begin{tabular}{|c|c|c|c|}
\hline & Product, Process & Product, Process, Organizational & Product, Process, Automation \\
\hline Fixed part & & & \\
\hline Process Innovation Only & $\begin{array}{l}-0.007 \\
(0.01)\end{array}$ & $\begin{array}{l}-0.001 \\
(0.03)\end{array}$ & $\begin{array}{l}0.000 \\
(0.02)\end{array}$ \\
\hline Organizational only & & $\begin{array}{l}-0.004 \\
(0.03)\end{array}$ & \\
\hline Automation only & & & $\begin{array}{c}-0.033^{*} \\
(0.02)\end{array}$ \\
\hline Growth new sales & $\begin{array}{c}0.962 * * * \\
(0.08)\end{array}$ & $\begin{array}{c}1.023 * * * \\
(0.12)\end{array}$ & $\begin{array}{c}0.961 * * * \\
(0.09)\end{array}$ \\
\hline Size 20 to 99 & $\begin{array}{c}-0.038 * * * \\
(0.01)\end{array}$ & $\begin{array}{c}-0.080 * * * \\
(0.02)\end{array}$ & $\begin{array}{c}-0.038 * * * \\
(0.01)\end{array}$ \\
\hline Size over 100 & $\begin{array}{c}-0.063 * * * \\
(0.01)\end{array}$ & $\begin{array}{c}-0.109 * * * \\
(0.02)\end{array}$ & $\begin{array}{c}-0.063 * * * \\
(0.01)\end{array}$ \\
\hline Constant & $\begin{array}{c}0.032 * * * \\
(0.01)\end{array}$ & $\begin{array}{c}0.058^{* *} \\
(0.03)\end{array}$ & $\begin{array}{c}0.032 * * * \\
(0.01)\end{array}$ \\
\hline \multicolumn{4}{|l|}{ Random Part } \\
\hline$\Psi_{11}$ & $\begin{array}{c}0.038 * * * \\
(0.01)\end{array}$ & $\begin{array}{c}0.090 \text { **** } \\
(0.02)\end{array}$ & $\begin{array}{c}0.048 * * * \\
(0.01)\end{array}$ \\
\hline$\Psi_{22}$ & $\begin{array}{c}0.243 * * * \\
(0.01)\end{array}$ & $\begin{array}{c}0.198 * * * \\
(0.02)\end{array}$ & $\begin{array}{c}0.242 * * * \\
(0.01)\end{array}$ \\
\hline$\theta$ & $\begin{array}{c}0.432 * * * \\
(0.00)\end{array}$ & $\begin{array}{c}0.413 * * * \\
(0.01)\end{array}$ & $\begin{array}{c}0.432 * * * \\
(0.00)\end{array}$ \\
\hline $\begin{array}{l}\mathrm{N} \\
\text { Pseudo log-likelihood } \\
\text { LR test }\end{array}$ & $\begin{array}{c}11762 \\
-7154.07 \\
0.00\end{array}$ & $\begin{array}{c}3696 \\
-2114.88 \\
0.00\end{array}$ & $\begin{array}{c}11762 \\
-7153.14 \\
0.00\end{array}$ \\
\hline $\begin{array}{l}\text { Note: Coefficients and standard en } \\
\text { and *, respectively. Standard error } \\
\text { growth in sales of old product). In } \\
\text { invests in } R \& D \text {. Based on multilev }\end{array}$ & $\begin{array}{l}\mathrm{S} \text { robust to heterosked } \\
\text { omputed using 5,000 } \\
\text { imental variables are } \\
\text { mixed-effects linear } \mathrm{r}\end{array}$ & $\begin{array}{l}\text { isticity and } 1,5 \text {, and } 10 \text { percent levels of } s \\
\text { ootstrapped replications. Dependent vari } \\
\text { ndicator whether new product is complete } \\
\text { gression with random intercept and slope }\end{array}$ & $\begin{array}{l}\text { ificicance are denoted by } * * *, * * \\
\text { e is net labor growth (minus } \\
\text { new to the firm and whether firms } \\
g_{2} \text { within country and sector. }\end{array}$ \\
\hline
\end{tabular}




\section{Table 10: Regressions of Random Coefficients on Innovation intensities}

\begin{tabular}{|c|c|c|c|c|c|c|}
\hline & \multicolumn{2}{|c|}{ Product \& Process } & \multicolumn{2}{|c|}{ Automation } & \multicolumn{2}{|c|}{ Organizational } \\
\hline & (1) & (2) & (3) & (4) & (5) & (6) \\
\hline Share product innovation & $\begin{array}{c}0.045^{* *} \\
(0.02)\end{array}$ & $\begin{array}{l}0.041 * \\
(0.02)\end{array}$ & $\begin{array}{l}0.043 \\
(0.03)\end{array}$ & $\begin{array}{l}0.036 \\
(0.03)\end{array}$ & $\begin{array}{l}0.018 \\
(0.02)\end{array}$ & $\begin{array}{l}0.023 \\
(0.02)\end{array}$ \\
\hline Share product and process innovation & $\begin{array}{l}-0.025 \\
(0.03)\end{array}$ & $\begin{array}{l}-0.007 \\
(0.04)\end{array}$ & $\begin{array}{l}0.078 \\
(0.07)\end{array}$ & $\begin{array}{l}0.101 \\
(0.07)\end{array}$ & $\begin{array}{l}-0.026 \\
(0.02)\end{array}$ & $\begin{array}{l}-0.032 \\
(0.03)\end{array}$ \\
\hline Share product and automation & & & $\begin{array}{c}-0.244 * * \\
(0.11)\end{array}$ & $\begin{array}{c}-0.244 * * \\
(0.11)\end{array}$ & & \\
\hline Share product and organizational & & & & & $\begin{array}{l}-0.028 \\
(0.02)\end{array}$ & $\begin{array}{l}-0.027 \\
(0.02)\end{array}$ \\
\hline Constant & $\begin{array}{c}0.955^{* * * *} \\
(0.00)\end{array}$ & $\begin{array}{c}0.951 * * * \\
(0.00)\end{array}$ & $\begin{array}{c}0.952^{* * * *} \\
(0.00)\end{array}$ & $\begin{array}{c}0.948^{* * *} \\
(0.01)\end{array}$ & $\begin{array}{c}1.026 * * * \\
(0.01)\end{array}$ & $\begin{array}{c}1.019^{* * *} \\
(0.01)\end{array}$ \\
\hline $\mathrm{N}$ & 306 & 306 & 306 & 306 & 284 & 284 \\
\hline Sector dummy & No & Yes & No & Yes & No & Yes \\
\hline R-Squared & 0.02 & 0.07 & 0.05 & 0.10 & 0.01 & 0.05 \\
\hline Pseudo log-likelihood & 588.81 & 596.65 & 521.88 & 529.38 & 369.92 & 376.08 \\
\hline
\end{tabular}

Note: Dependent variable in all regressions is random slope parameters for country/sector clusters derived from (4). Independent variables are respective innovation rates - share of innovators in each country/sector cluster. Coefficients and standard errors robust to heteroskedasticity and 1, 5, and 10 percent levels of significance are denoted by $* * *, * *$ and $*$, respectively. Standard errors computed using 5,000 bootstrapped replications. Based on 306 country sectors with at least 10 observations. Source: Enterprise Surveys 2013-2015. 
${ }^{1}$ We are grateful for helpful comments seminar participants at the 10th IZA/World Bank conference on Technological Change and Jobs (Bonn, Germany), the 6th ZEW/MaCCI Conference on the Economics of Innovation and Patenting (Mannheim, Germany) and this volume editors. We would like to thank Jordi Jaumeandreu for extensive comments to an earlier version of this paper, Jean-Louis Combes for discussing our paper and sharing comments at a seminar presentation at CERDI, and CIIP for financial assistance. Corresponding Author: The World Bank, Firm Capabilities and innovation, Finance, Competitiveness and Innovation Global Practice, Washington, D.C. Email: xcirera@worldbank.org

${ }^{2}$ Lentz and Mortensen (2008), using Danish firm-level data, find that up to $75 \%$ of productivity growth comes from reallocation of inputs to innovating firms, of which $25 \%$ is entry and exist of firms and $50 \%$ reallocation to growing innovative firms.

${ }^{3}$ Some important studies include Harrison, Jaumandreu, Mairesse, and Peters (2014) for France, Germany, Spain, and the United Kingdom, Hall, Lotti, and Mairesse (2008) for Italy, Dachs and Peters (2014) for European countries and Benavente and Lauterbach (2008) for Chile. Also, see Castillo, Maffioli, Rojo, and Stucchi (2014), Brown, Earle, and Lup (2005) for effects of innovation policies on firm performance.

${ }^{4}$ The total residual is $\xi_{i j} \equiv \xi_{1 j}+\xi_{2 j} x_{i j}+\varepsilon_{i j}$ and its conditional variance is $\operatorname{Var}\left(\xi_{i j} \mid \mathrm{x}_{\mathrm{ij}}\right)=\psi_{11}+2 \psi_{21} x_{i j}+\psi_{22} \mathrm{x}_{i j 2}+\theta$, where the level-1 residual is assumed homoskedastic and with conditional variance $\operatorname{Var}\left(\varepsilon_{i j} \mid \mathrm{x}_{\mathrm{ij}}, \psi_{i j}\right)=\theta$.

${ }^{5}$ The default case sets $\psi_{21}$ and the corresponding correlation coefficient to zero but this assumption can be relaxed using the option covariance (unstructured).

${ }^{6}$ Alternatively, it can also be estimated using empirical Bayes as described in Rabe-Hesketh and Skrondal (2012).

7 Sector breakdown is usually manufacturing, retail, and other services. For larger economies, specific manufacturing sub-sectors are selected as additional strata on the basis of employment, value-added, and total number of establishments' figures. Geographic regions within a country are selected based on which cities/regions collectively contain the majority of economic activity. Enterprise Surveys implemented in Eastern Europe and Central Asian countries are also known as Business Environment and Enterprise Performance Surveys (BEEPS) and are jointly conducted by the World Bank and the European Bank for Reconstruction and Development. For more details see Enterprise Surveys (http://www.enterprisesurveys.org).

${ }^{8}$ Overall both product and process innovation rates fall from $37 \%$ to $31 \%$.

9 DRC, Ghana, Kenya, Namibia, Nigeria, South Sudan, Sudan, Tanzania, Uganda, Zambia, Malawi, Bangladesh, India, Nepal, Pakistan, Albania, Armenia, Azerbaijan, Belarus, Bosnia and Herzegovina, Bulgaria, Croatia, Czech Republic, Estonia, Georgia, Hungary, Kazakhstan, Kosovo, Kyrgyzstan, Latvia, Lithuania, Macedonia, Moldova, Mongolia, Montenegro, Poland, Romania, Russia, Serbia, Slovakia, Slovenia, Tajikistan, Turkey, Ukraine, Uzbekistan, Egypt, Israel, Jordan, Lebanon, Morocco, Tunisia, West Bank and Yemen.

${ }^{10}$ An alternative to splitting the sample by region and income groups would be to estimate the full sample and include interaction terms. However, the potential endogeneity of the innovation sales to employment changes described in previous sections makes it very difficult to find suitable instruments for the interactive terms.

${ }^{11}$ The size and country-sector dummies are restricted to add up to zero.

11 To isolate which process innovations fell under the category of automation, we relied upon the actual descriptions of the innovation as opposed to whether a process innovation was self-reported as automation as a robustness check. We first scanned for keywords in the process innovation description such as "automate", "robots", "manual" and then inspected each description individually for an indication that new machinery or equipment was introduced to facilitate or reduce human labor in the production process. 